\title{
Karakterisasi Bunga Tetua Anggrek Dendrobium dalam Menghasilkan Variasi Fenotipe Baru Melalui Teknik Hibridisasi
}

\author{
Characteristic Flower of The Parental Dendrobium Orchid \\ in Producing Phenotypic Variations with Hybridization Technique
}

\author{
Muhammad Ni'amul Albab*, Tintrim Rahayu, Gatra Ervi Jayanti \\ Jurusan Biologi, Fakultas Matematika dan Ilmu Pengetahuan Alam, Universitas Islam Malang \\ Jl. Mayjen Haryono 193, Malang, 65144, Indonesia \\ *Email : luguimpharator@gmail.com
}

Diterima 28 Juli 2021 / Disetujui 29 Agustus 2021

\begin{abstract}
ABSTRAK
Peningkatan mutu pada tanaman anggrek juga dapat ditingkatkan pada teknik persilangan dan perbanyakan biji hasil persilangan. Kegiatan persilangan banyak menggunakan varietas-varietas dengan tetua yang sama sehingga menyebabkan variasi genetik pada hibrida yang terbentuk menjadi terbatas. Tujuan penelitian ini adalah untuk mendeskripsikan karakteristik bunga tetua anggrek Dendrobium yang digunakan sebagai indukan dan menganalisis bunga pada generasi hasil persilangan. Penelitian ini menggunakan metode kualitatif dengan cara mendeskripsikan karakteristik bunga tetua anggrek dengan variasi berbeda serta bunga pada anggrek hibrida hasil persilangan. Analisis dilakukan melalui pendekatan morfologi secara langsung. Hasil yang diperoleh adalah anggrek hibrida hasil persilangan yang telah berbunga memiliki morfologi bunga yang mirip seperti kedua tetua persilangannya seperti ukuran bunga, warna bunga, bentuk dan warna sepal maupun petal, dan warna dari labellum tergantung dari karakteristik bunga yang terdapat pada kedua tetua persilangannya. Kesimpulan yang didapat berupa pemilihan tetua persilangan ditentukan sesuai karakter bunga yang dikehendaki sehingga menghasilkan generasi yang memiliki variasi bunga baru dan bunga dari anggrek hibrida yang dihasilkan dari pemuliaan anggrek memiliki campuran karakteristik bunga dari kedua tetua anggrek yang digunakan sebagai indukan persilangan, tetapi tidak semua karakter bunga dari kedua tetua muncul, ada beberapa karakter bunga yang muncul dari salah satu tetua.
\end{abstract}

Kata kunci: karakteristik, hibridisasi, bunga, tetua, dendrobium

\begin{abstract}
Improving the quality of orchid plants can also be improved on the technique of crossing and seed propagation from crosses. Crossing activities use a lot of varieties with the same parents, causing genetic variation in the hybrids formed to be limited. The purpose of this study was to describe the characteristics of the flower of the Dendrobium orchid parent used as a parent and to analyze the flower in the generation of crosses. This study uses a qualitative method by describing the characteristics of the flower of elder orchids with different variations and the flowers on hybrid orchids from crosses. The analysis was carried out through a direct morphological approach. The results obtained are hybrid orchids that have flowered from crosses that have flower morphology that is similar to the two parents of the cross, such as flower size, flower color, shape and color of the sepals and petals, and the color of the labellum depending on the characteristics of the flowers found in the two parents of the cross. The conclusion obtained in the form of the selection of the crossing parent is determined according to the desired flower character to produce a generation that has new flower variations and flowers from hybrid orchids produced from orchid breeding have a mixture of floral characteristics from the two orchid elders used as cross breeders, but not all flower characters. from the two elders who appeared, several flower characters emerged from one of the elders.
\end{abstract}

Keywords: characteristics, hybridization, flower, parental, dendrobium 


\section{PENDAHULUAN}

Dendrobium berasal dari kata "dendro" yang berarti pohon dan "bios" yang berarti hidup. Anggrek ini mempunyai bunga yang menawan dan jenisnya juga termasuk yang terbanyak (Parnata, 2007). Dendrobium merupakan anggrek tipe simpodial yaitu dapat mengeluarkan tangkai bunga baru di sisi-sisi batangnya (Prasetyo, 2009)

Bunga anggrek menunjukkan variasi yang sangat luas dalam bentuk, tatanan/formasi, ukuran, dan warna melebihi keragaman bunga dari semua divisi Angiospermae lainnya. Oleh sebab itu, anggrek sangat dihargai dalam aktifitas komersial sebagai tanaman pot atau bunga potong (Kishor dkk 2005). Eksploitasi tanpa pembudidayaan menyebabkan penurunan potensi anggrek alam sebagai tetua persilangan. Selain itu, pengetahuan mengenai sifat-sifat penurunan karakter anggrek alam masih sedikit dikaji dan diketahui sehingga pemanfaatan anggrek spesies sebagai induk persilangan belum maksimal (Balai Penelitian Tanaman Hias, 2015). Persilangan dengan menggunakan anggrek hibrida juga memiliki kelemahan yaitu silsilah tetua persilangan biasanya sulit untuk dilacak dan diperoleh, kegiatan persilangan juga banyak mengabaikan penulusuran informasi tetua persilangan, sehingga identitas karakter anggrek hasil persilangan menjadi tidak jelas (Zulkhaidah dkk., 2010).

Keanekaragaman pada anggrek dapat dipelajari dari aspek morfologi dan anatomi. Pengamatan morfologi lebih mudah dilakukan karena karakter yang dominan dapat ditemukan di beberapa bagian tanaman (Sabran dkk, 2003). Selain itu, karakteristrik morfologi lebih mudah dipahami karena langsung dapat dilihat oleh mata dan nampak secara jelas dibandingkan dengan karaktersitik molekuler (Ainiah dkk, 2017). Secara morfologi diperlukan kegiatan karakterisasi untuk seleksi varietas plasma nutfah anggrek asli. Karakterisasi morfologi meliputi proses identifikasi dan dokumentasi yang bertujuan untuk mendapatkan karakter fenotipik tanaman (Hartarti dan Darsana, 2015). Pengamatan karakter morfologi dapat dilakukan pada seluruh bagian tumbuhan yang meliputi batang, bunga, daun, akar, dan buah (Yusran dan Maemunah, 2011).
Salah satu upaya untuk meningkatkan mutu bunga anggrek di Indonesia adalah dengan cara merakit tanaman-tanaman baru melalui kegiatan pemuliaan. Salah satunya yaitu dengan menyilangkan tetua dengan karakter-karakter yang dikehendaki untuk mendapatkan kultivar baru. Persilangan tanaman anggrek mempunyai sasaran peningkatan keragaman genetik pada bentuk dan warna yang unik, disenangi konsumen, frekuensi berbunga tinggi, dan tahan terhadap hama atau penyakit serta cekaman lingkungan (Soedjono, 1997).

Tujuan dari pemuliaan adalah untuk mensistesis genus spesies utama dengan karakter lain dan ditingkatkan dalam generasi F1 (Vij, 1986). Penelitian tentang hubungan kekerabatan berdasarkan morfologi tanaman anggrek pada bagian bunga, batang, dan daun perlu dilakukan agar hasil dari penelitian tersebut dapat digunakan sebagai data untuk mempermudah membedakan karakteristik antara spesies anggrek Dendrobium yang satu dengan lainnya.

\section{METODE PENELITIAN}

Penelitian ini dilaksanakan pada tanggal 1 Februari 2021 - 1 Maret 2021 dikebun anggrek Dede Orchid Nursery, Batu Malang. Penelitian ini menggunakan metode kualitatif dengan cara mendeskripsikan karakteristik bunga tetua anggrek dengan variasi berbeda serta bunga pada anggrek hibrida hasil persilangan. Analisis dilakukan melalui pendekatan morfologi secara langsung. Alat yang digunakan dalam penelitian ini ada tusuk gigi, pulpen, buku catatan, buku panduan deskripsi tanaman, kamera, kertas label, dan benang. Bahan yang digunakan sebagai tetua persilangan yaitu $D$. lasianthera, $D$. violaceoflavens, $D$. nindii, $D$. taurinum, D. Damarwulan, D. Kim Bora, dan D. Carl Ludwig Bundt.

\section{HASIL DAN PEMBAHASAN}

Pada Gambar 1, persilangan Dendrobium Rizki Kartika merupakan persilangan interspecific hybrid. Anggrek Dendrobium Rizki Kartika merupakan anggrek hibrida yang dihasilkan dari persilangan tetua anggrek. spesies Dendrobium 
lasianthera sebagai seed parent (betina) dan tetua anggrek hibrid Dendrobium Damarwulan sebagai pollen parent (jantan). Karakteristik bunga pada anggrek Dendrobium Rizki Kartika memiliki ukuran labellum 2.2-2.4 x 1.3-1.5 cm berwarna merah muda, dengan ukuran petal $3-5 \mathrm{~cm}$ yang panjang melintir berwarna ungu gelap dan ukuran sepal $2.6 \mathrm{~cm}$ yang menggulung berwarna sama. Warna pada labellum Dendrobium Rizki Kartika diturunkan dari tetua anggrek Dendrobium Damarwulan yang memiliki labellum berwarna merah muda. Karakter bentuk petal diturunkan oleh gabungan dari kedua petal tetuanya yang memiliki karakter petal panjang dari tetua Dendrobium Damarwulan dan melintir dari tetua Dendrobium lasianthera, tetapi pada warna petalnya diturunkan dari tetua Dendrobium lasianthera yang berwarna merah gelap, sedangkan bentuk sepal yang menggulung diturunkan oleh tetua Dendrobium Damarwulan. Pada tetua anggrek Dendrobium lasianthera memiliki karakter sepal dan petal yang melintir tetapi pendek, sedangkan petal pada tetua anggrek Dendrobium Damarwulan memiliki karakter panjang tetapi tidak terlalu melintir dan sepalnya menggulung

\section{q Seed Parent:}

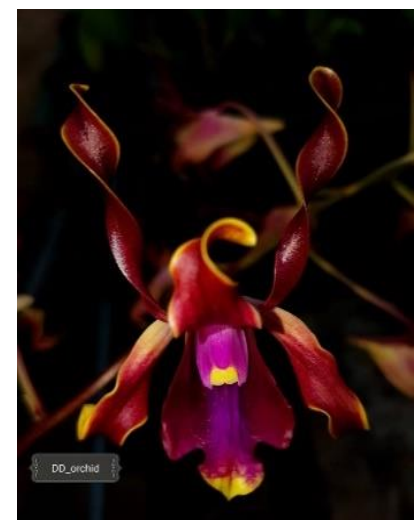

Dendrobium lasianthera
§. Pollen Parent:

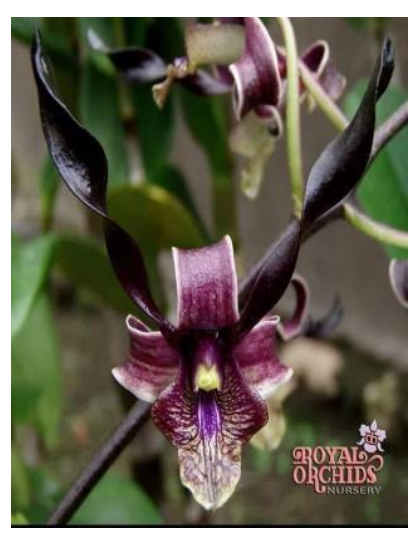

Dendrobium Damarwulan

F1:

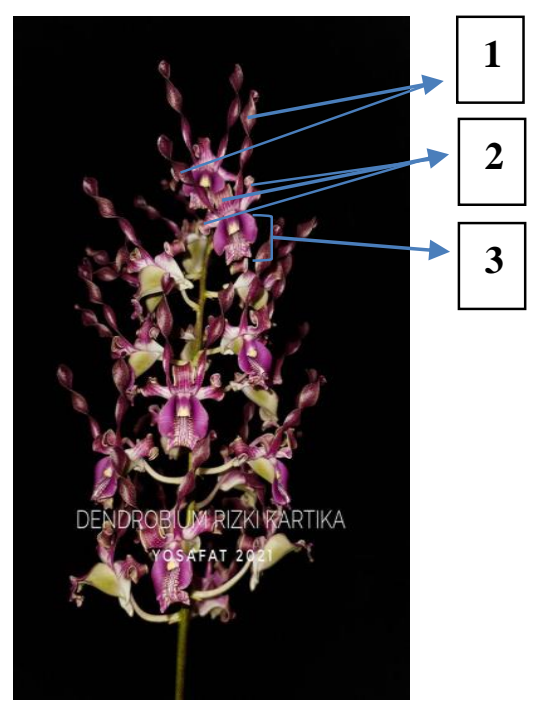

Dendrobium Rizki Kartika

Gambar 1. Persilangan Dendrobium Rizki Kartika, (1) Petal, (2) Sepal, (3) Labellum 
+ Seed Parent:

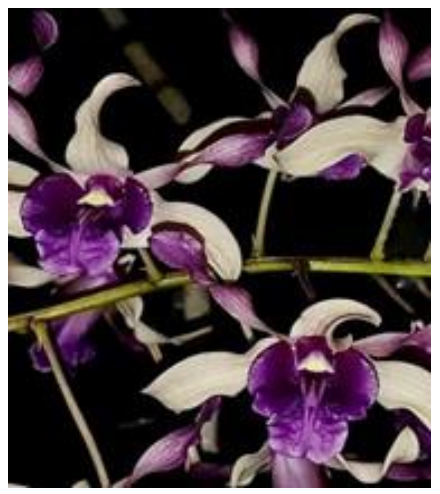

Dendrobium Kim Bora §ollen Parent:

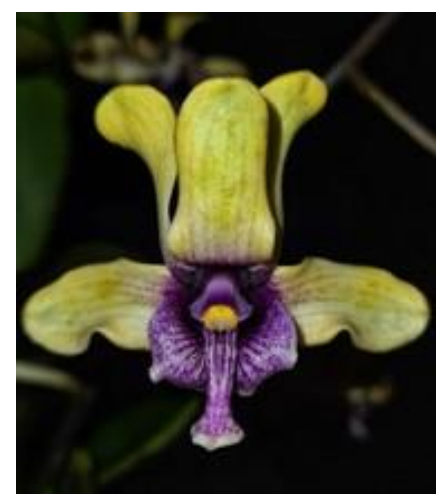

Dendrobium violaceoflavens

F1:

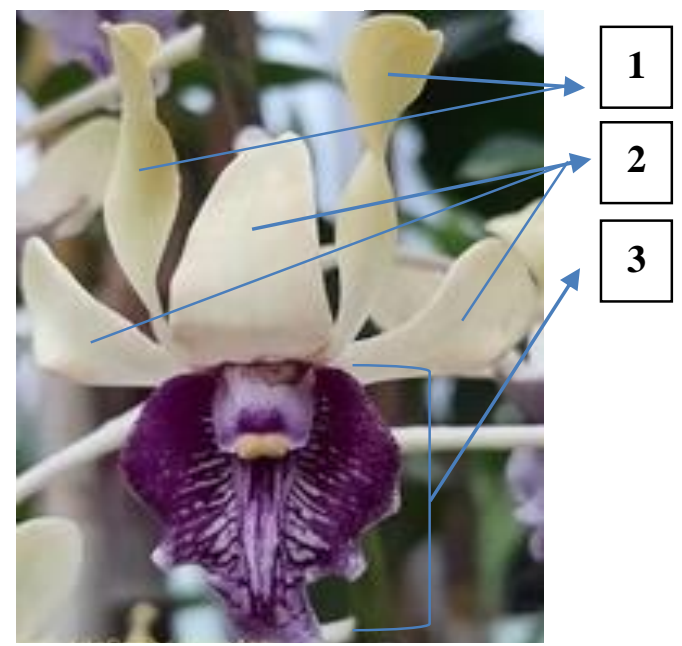

Dendrobium Imelda Marini Masagung

Gambar 2. Persilangan Dendrobium Imelda Marini Masagung, (1) Petal, (2) Sepal, (3) Labellum

Pada Gambar 2, persilangan Dendrobium Imelda Marini Masagung merupakan persilangan interspecific hybrid. Dendrobium Imelda Marini Masagung merupakan anggrek hibrida yang dihasilkan dari persilangan tetua anggrek hibrid Dendrobium Kim Bora sebagai seed parent (betina) dan tetua anggrek spesies Dendrobium violaceoflavens sebagai pollen parent (jantan). Karakteristik bunga pada anggrek Dendrobium Imelda Marini Masagung memiliki ukuran labellum 2.5-3.2 x 1.75-1.9 cm berwarna ungu, dengan ukuran petal $2.4 \mathrm{~cm}$ yang pendek, tegak, berwarna putih kekuningan dan ukuran sepal $2.75 \mathrm{~cm}$ yang lebar tetapi tidak menggulung berwarna sama. Warna pada labellum Dendrobium Imelda Marini Masagung diturunkan dari kedua tetua yang samasama berwarna ungu yaitu Dendrobium Kim Bora dan Dendrobium violaceoflavens. Karakter petal dari bunga anggrek Dendrobium Imelda Marini Masagung diturunkan dari gabungan kedua karakter petal tetuanya, dengan ukuran petal yang pendek dan tegak dari tetua Dendrobium violaceoflavens dan bentuk sedikit melintir dari petal tetua Dendrobium Kim Bora, serta warna petal Dendrobium Imelda Marini Masagung merupakan campuran dari kedua tetuanya. 
q Seed Parent:

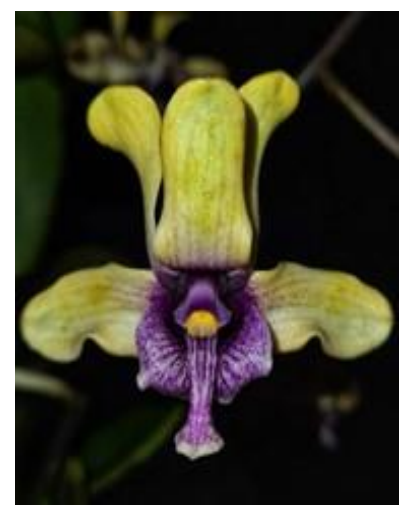

Dendrobium violaceoflavens
§ Pollen Parent:

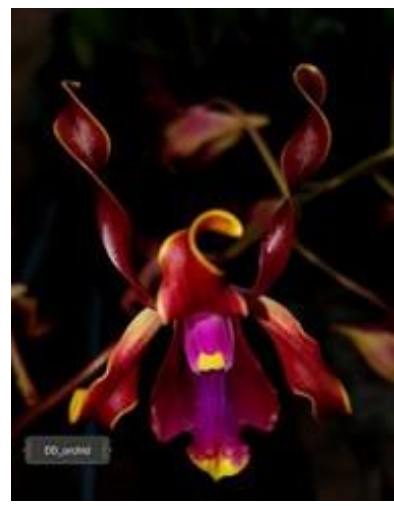

Dendrobium lasianthera

F1:

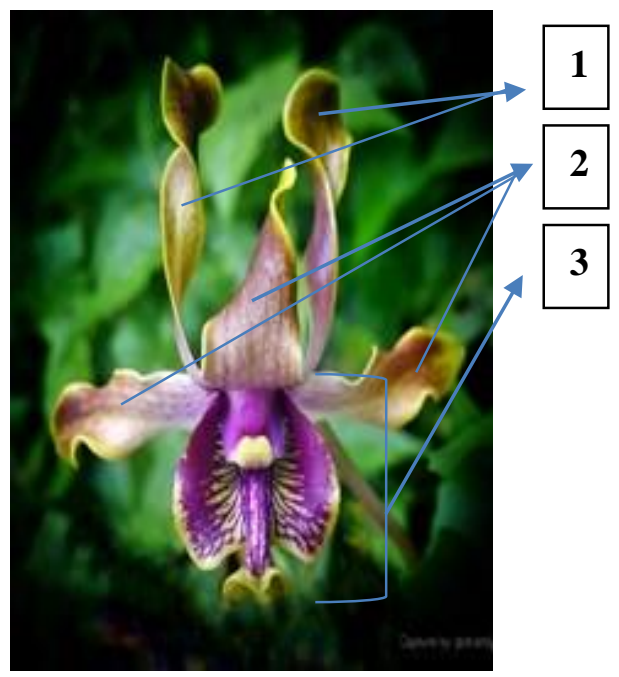

Dendrobium Budiono Lamtoro

Gambar 3. Persilangan Dendrobium Budiono Lamtoro. (1) Petal, (2) Sepal, (3) Labellum

Pada Gambar 3, persilangan anggrek Dendrobium Budiono Lamtoro merupakan persilangan interspecific hybrid. Dendrobium Budiono Lamtoro merupakan anggrek hibrida yang dihasilkan dari persilangan tetua anggrek spesies Dendrobium violaceoflavens sebagai seed parent (betina) dan tetua anggrek spesies Dendrobium lasianthera sebagai pollen parent (jantan). Anggrek Dendrobium Budiono Lamtoro memiliki ukuran labellum 3.6-4.75 x 1.75-1.9 cm berwarna ungu dengan corak garis putih di dalamnya. Memiliki ukuran petal 3.5-4.4 x 0.4-0.65 cm dengan bentuk sedikit melintir, pendek dan lapisan atas berwarna oranye dengan garis tepi berwarna hijau dan bagian lapisan bawah berwarna merah muda. Memiliki sepal berukuran 2.5-3.2 x $1.1 \mathrm{~cm}$ dengan bentuk yang lebar, sedikit melintir, dan berwarna sama seperti warna petalnya. Warna ungu dan corak putih pada labellum Dendrobium Budiono Lamtoro diturunkan dari karakter tetua Dendrobium violaceoflavens, sedangkan untuk warna pada sepal dan petalnya diturunkan dari campuran kedua warna tetuanya, dimana garis tepi berwarna hijau dari tetua Dendrobium violaceoflavens dan warna oranye dari tetua Dendrobium lasianthera. Bentuk sepalnya diturunkan dari karakter tetua Dendrobium violaceoflavens yang lebar tetapi bentuk sepalnya diturunkan oleh tetua Dendrobium 
lasianthera yang sedikit melintir. Petal memiliki bentuk tegak, panjang, dan sedikit melintir diturunkan dari gabungan kedua tetuanya yang memiliki petal panjang, melintir dari Dendrobium lasianthera dan tegak dari Dendrobium violaceoflavens q Seed Parent:

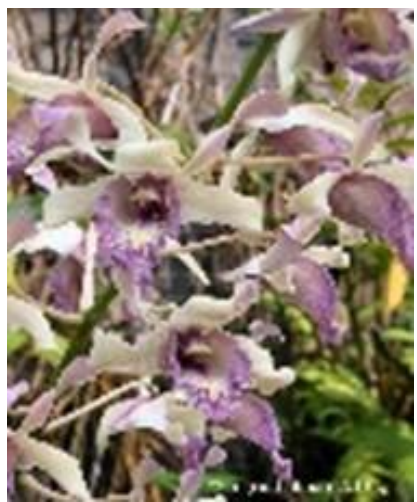

Dendrobium nindii ôllen Parent:

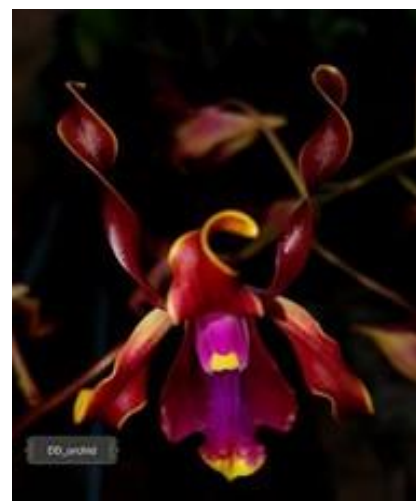

Dendrobium lasianthera

F1:

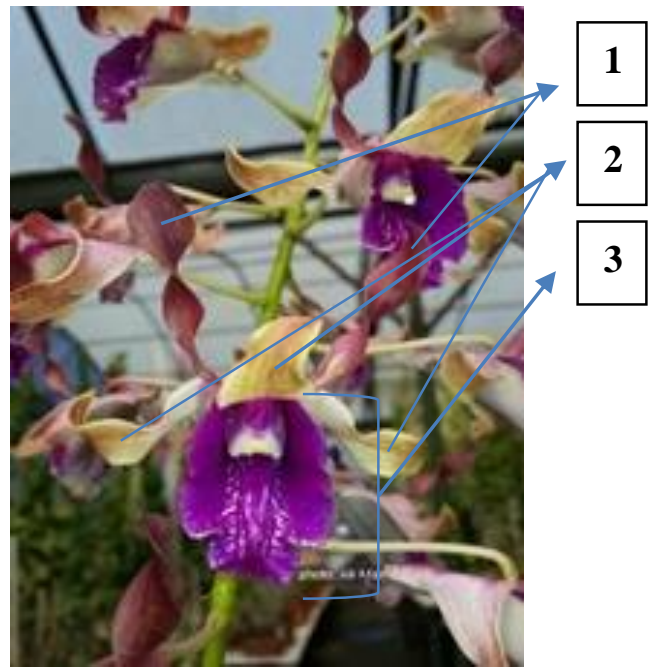

Dendrobium Carl Ludwig Bundt

Gambar 4. Persilangan Dendrobium Carl Ludwig Bundt. (1) Petal, (2) Sepal, (3) Labellum

Pada Gambar 4, persilangan Dendrobium Carl Ludwig Bundt merupakan persilangan interspecific hybrid. Dendrobium Carl Ludwig Bundt merupakan anggrek hibrida yang dihasilkan dari persilangan tetua anggrek spesies Dendrobium nindii sebagai seed parent (betina) dan tetua anggrek spesies Dendrobium lasianthera sebagai pollen parent (jantan). Karakteristik dari bunga anggrek Dendrobium Carl Ludwig Bundt memiliki ukuran labellum 3-4 x 1-1.2 cm berwarna ungu dengan ukuran sepal 2.6-4 x 0.8-1.2 cm yang memiliki bentuk sedikit menggulung berwarna kuning cerah dan ukuran petal 3-5 x 0.5-0.6 cm yang tegak, pendek, dan melintir. Warna labellumnya diturunkan dari kedua tetuanya yang sama-sama memiliki labellum berwarna ungu. Bentuk petal yang melintir juga sama seperti bentuk petal dari tetuanya yaitu Dendrobium lasianthera, 
tetapi warnanya sedikit cerah karena terdapat campuran warna ungu cerah dari warna petal tetuanya yaitu Dendrobium nindii, sedangkan bentuk sepal diturunkan dari tetua Dendrobium lasianthera yang menggulung dan memiliki warna kuning cerah karena campuran dari warna sepal Dendrobium lasianthera yang berwarna merah gelap dan warna sepal dari Dendrobium nindii yang berwarna putih
+ Seed Parent:

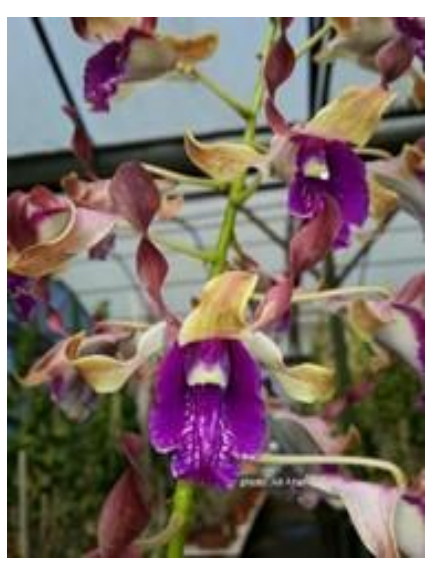

Dendrobium Carl Ludwig Bundt ô Pollen Parent:

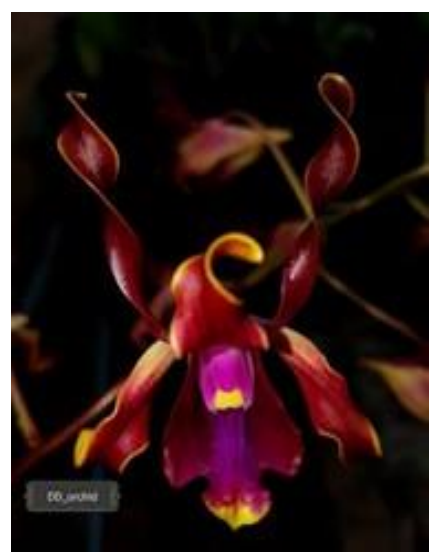

Dendrobium lasianthera

F1:

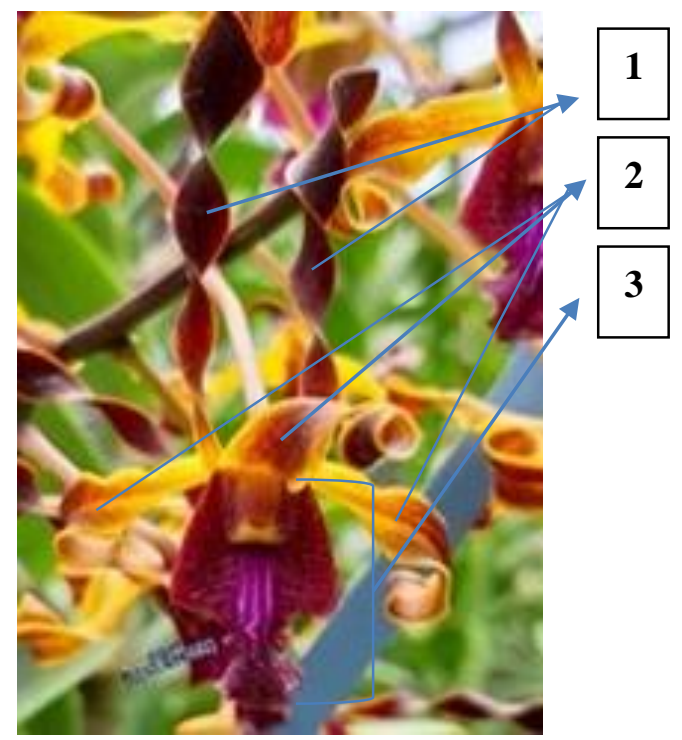

Dendrobium Celebes Star

Gambar 5. Persilangan Dendrobium Celebes Star. (1) Petal, (2) Sepal, (3) Labellum

Pada Gambar 5, persilangan Dendrobium Celebes Star merupakan persilangan interspecific hybrid. Dendrobium Celebes Star merupakan anggrek hibrida yang dihasilkan dari persilangan tetua anggrek hibrid Dendrobium Carl Ludwig Bundt sebagai seed parent (betina) dan tetua anggrek spesies Dendrobium lasianthera sebagai 
pollen parent (jantan). Karakteristik dari bunga anggrek Dendrobium Celebes Star memiliki ukuran labellum 3.6-4.75 x 1.75-1.9 cm berwarna merah gelap dengan corak berwarna ungu dan ukuran petal 4-4.4 x 0.4-0.6 cm yang panjang serta melintir berwarna merah gelap serta pangkal dan pinggiran petal berwarna kuning, sedangkan sepal memiliki
+ Seed Parent:

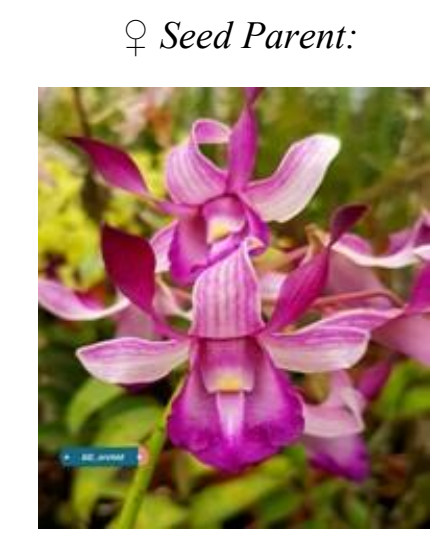

Dendrobium taurinum

Dendrobium tauninum ukuran 2.7-3.5 x $1.7 \mathrm{~cm}$ dengan bentuk yang menggulung berwarna sama seperti petal. Warna dari labellumnya merupakan perpaduan dari warna yang dimiliki oleh tetuanya, seperti warna ungu diturunkan dari tetuanya yaitu Dendrobium Carl Ludwig Bundt dan warna merah gelap dari tetua Dendrobium lasianthera..

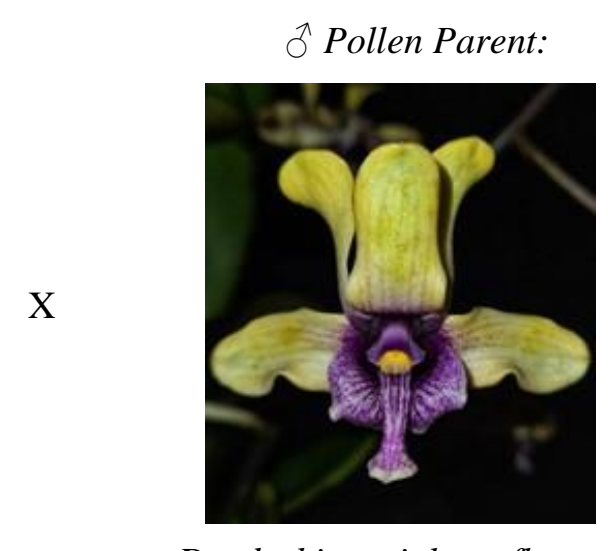

Dendrobium violaceoflavens

F1:

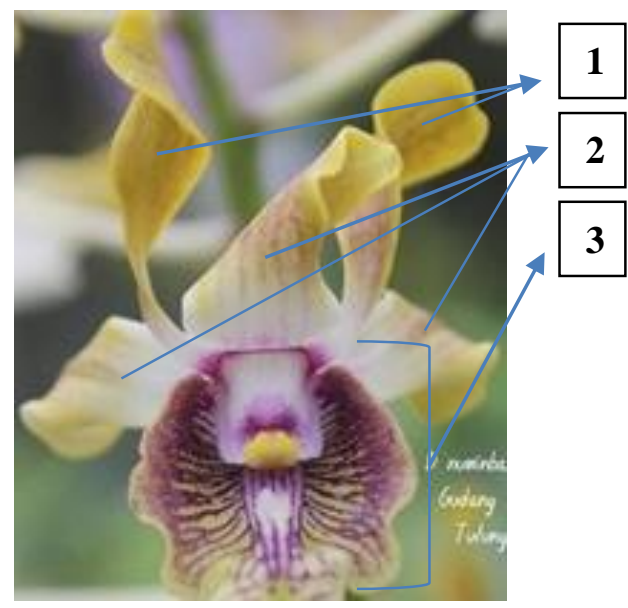

Dendrobium Numinbah Beauty

Gambar 6. Persilangan Dendrobium Numinbah Beauty. (1) Petal, (2) Sepal, (3) Labellum

\begin{abstract}
Pada Gambar 6, persilangan Dendrobium Numinbah Beauty merupakan persilangan interspecific hybrid. Dendrobium Numinbah Beauty merupakan anggrek hibrida yang dihasilkan dari persilangan tetua anggrek spesies Dendrobium taurinum sebagai seed parent (betina) dan tetua anggrek spesies Dendrobium violaceoflavens sebagai pollen parent (jantan). Karakteristik dari bunga anggrek Dendrobium Numinbah Beauty memiliki ukuran labellum 2.5-3.2 x 2-2.3 cm
\end{abstract}

berwarna dasar hijau cerah dengan motif berwarna ungu. Memiliki ukuran sepal $2.75 \mathrm{~cm}$ yang berbentuk lebar dan menggulung, serta memiliki warna hijau cerah dengan warna pangkalnya putih, sedangkan ukuran petalnya $2.4 \mathrm{~cm}$ memiliki bentuk pendek, sedikit melintir, dan berwarna seperti sepal. Warna dari bunganya diturunkan oleh tetua Dendrobium violaceoflavens yang berwarna hijau cerah, tetapi untuk bentuk sepal dan petalnya diturunkan oleh tetua Dendrobium taurinum yang 
memiliki bentuk sepal menggulung dan petalnya sedikit melintir.

\section{KESIMPULAN}

Bunga dari anggrek hibrida yang dihasilkan dari pemuliaan anggrek memiliki campuran karakteristik bunga dari kedua tetua anggrek yang digunakan sebagai indukan persilangan, tetapi tidak semua karakter bunga dari kedua tetua muncul, ada beberapa karakter bunga yang muncul dari salah satu tetua. Pemilihan tetua persilangan ditentukan sesuai karakter yang bunga yang dikehendaki sehingga menghasilkan generasi yang memiliki variasi bunga baru.

\section{UCAPAN TERIMA KASIH}

Penulis mengucapkan terima kasih kepada Dede Orchid Nursery yang telah menyediakan semua bahan dan alat yang diperlukan dalam penelitian ini.

\section{DAFTAR PUSTAKA}

Ainiah J., T. Rahayu., \& A. Hayati. (2017). Analisis Karakter Fenotip Beberapa Spesies Anggrek Dendrobium. Jurnal Ilmiah Biosaintropis: 2(5), 10-16. ISSN :2460-9455 (e) - 2338-2805(p)

Balai Penelitian Tanaman Hias. (2015). Pemuliaan anggrek. Iptek Hortikultura. 7 (11).

Hartarti S., L. Darsana. (2015). Karakterisasi Anggrek Alam secara Morfologi dalam Rangka Pelestarian Plasma Nutfah.

Jurnal Agronomi Indonesia: 2 (43). 133-139.

Hawkes. (1965). Encyclopedia of cultivated orchids. Faber and Faber limited, London. Hal 485.

Parnata. (2007). Panduan Budidaya dan Perawatan Anggrek. Jakarta: Penerbit Agromedia Pustaka.

Prasetyo, C. H. (2009). Teknik Kultur Jaringan Anggrek Dendrobium Sp. Di Pembudidayaan Anggrek Widorokandang Yogyakarta. [Skripsi]. Yogyakarta: UNS.

Sabran M., A. Krismawati, Y. R. Galingging, M. A. Firmansyah. (2003). Eksploitasi dan Karakterisasi Anggrek di Kaliamntan Tengah. Buletin Plasma Nutfah: 1 (9). 1-2.

Soedjono. (1997). Pengaruh Waktu Perendaman dan Konsentrasi Kolkhisin Terhadap Pertumbuhan Protokorm Anggrek
Dendrobium. Jakarta. Jurnal Hortikukltura. Vol 6: 242-248 hlm.

Teixeira da Silva J.A, S. J. Zeng, J. Dobránszki, J. C. Cardoso, G. B. Kerbauy. (2014). In Vitro Flowering Of Dendrobium. Plant Cell Tissue Organ Cult; 119 (3): 447-456.

Vij, S.P., N. Shekhar. (1986). Cytogenetical Aspects Of Indian Orchids. In: Vij, S.P. (Ed.), Biology, Conservation and Culture of Orchids. Affliated East-West Press, New Delhi, India, pp. 189-220.

Yusran dan Maemunah. (2011). Morphology Characterization of Glutinous Corn Varietas in Ampana kota Surabaya sub Disrict of Tojo Una-una Regency. Jurnal Agroland: 1 (18). 36-42.

Zulkhaidah, Muslimin, A. S. Alam, B. Toknok. (2010). Peningkatan Mutu Tanaman Hias Anggrek Alam Phalaenopsis Melalui Kegiatan Persilangan. Abditani: Jurnal Pengabdian Masyarakat (1): 68-71. 